\title{
CONTRIBUIÇÃO DO GPS PARA O APRIMORAMENTO DO GEÓIDE NO ESTADO DE SÃO PAULO
}

\author{
Sérgio Florêncio de Souza \\ Orientador: Dr. Nelsi Cogo de Sá (IAG/USP) \\ 204p - Tese (Doutorado) - Defesa 03.10.2002
}

RESUMO. A determinação e o aprimoramento do geóide gravimétrico no Estado de São Paulo constituem o objetivo principal deste trabalho. Essa idéia foi colocada em prática com a determinação de dois modelos geoidais. 0 primeiro foi calculado utilizando a distribuição irregular dos dados (MDGI); o segundo, utilizando um modelo digital gerado a partir de dados gravimétricos e topográficos (MDGR). Na determinação desses geóides, foi utilizado o método da colocação por mínimos quadrados, que permite combinar dados do campo de gravidade resultantes de levantamentos gravimétricos terrestres e oceânicos, e das missões geodésicas de altimetria por satélite, dados topográficos, e coeficientes de modelos geopotenciais. Na avaliação dos geóides, determinados neste trabalho (MDGl e MDGR), e dois já existentes (MDG95 e EGM96), foi usada uma rede GPS densa, implantada sobre RNs, e ajustadas fixando estações da RBMC. Esses dados proporcionaram a avaliação dos modelos geoidais de forma absoluta e relativa. Na avaliação absoluta foram comparadas as alturas geoidais, obtidas por técnicas diferentes, nos mesmos pontos; na relativa, foram comparadas as diferenças de alturas geoidais entre pares de pontos. Os resultados mostraram que a componente sistemática é semelhante à encontrada em muitos países. Na avaliação relativa do geóide gravimétrico, obtida a partir de pares das diferenças entre 0 geóide gravimétrico e 0 geóide GPS, observa-se que as diferenças encontradas estão dentro das exigências para a utilização de modelos geoidais no nivelamento por satélite. Após a avaliação dos modelos geoidais, foi necessário compatibilizá-los com o do sistema altimétrico. 0 polinômio de segundo grau foi escolhido para representar a componente sistemática, e posteriormente, utilizado para compatibilizar esses geóides com o do sistema altimétrico. A metodologia usada neste trabalho, para a determinação e aprimoramento do geóide no Estado de São Paulo, constitui uma estratégia a ser aplicada em outras partes do Brasil e fornecer pr cisão para as alturas geoidais compatível com a do nivelamento.

ABSTRACT. The determination and the improvement of the gravimetric geoid in São Paulo State constitute the main objective of this work. This idea became reality with the determination of two geoid models. The first one was calculated from an irregular distribution of gravity data (MDGI); the second one computed from a digital gravity model and topographic data (MDGR). These geoids were computed by least squares collocation method, which allows to combine terrestrial and oceanic gravity data, satellite altimetry derived data, topographic data, and coefficients of geopotencial modelo. In the evaluation of the geoids determined in this work (MDGI and MDGR), and the two already existing ones (MDG95 and EGM96), was used a dense GPS network, established on benchmarks, and adjusted by fixing the RBMC stations net. These data have enabled the evaluation of the geoid models in absolute and relative ways. In absolute evaluation, the geoid heights computed in the same points by different techniques, have been compared; in the relative evaluation, the differences of geoid heights among pairs of points have been compared. The results showed that the systematic component is similar to that one encountered in many countries. In relative evaluation of the gravimetric geoid, accomplished from pairs of differences between the gravimetric geoid and GPS geoid, was observed that the differences satisfy the requirements for the use of these geoidal models in the satellite levelling. After the evaluation of geoidal models, it was necessary make them compatible with the altimetric system geoid. The second degree polynomial was chosen to represent the systematic component, and later on to make these geoids compatible with the altimetric system geoid. The methodology used in this work for the determination and improvement of the geoid in the São Paulo State, constitutes a strategy to be applied in other parts of Brazil, and to provide the precision the geoid heights compatible with that one of levelling. 